\title{
Ecosystem Services of UHE Carlos Botelho (Lobo/Broa): a new approach for management and planning of dams multiple-uses
}

\author{
Periotto, $N A .^{a} *$ and Tundisi, $J G^{b}$ \\ ${ }^{a}$ Post-Graduation Programme in Ecology and Natural Resources, Federal University of São Carlos - UFSCar, \\ São Carlos, SP, Brazil \\ ${ }^{b}$ International Institute of Ecology, Rua Bento Carlos 750, CEP 13560-660, São Carlos, SP, Brazil \\ e-mail: nataliaperiotto@gmail.com \\ Received: February 14, 2012 - Accepted: August 27, 2012 - Distributed: August 31, 2013
}

(With 2 figures)

\begin{abstract}
The aim of this study was to identify and make an initial accounting of the ecosystem services of the hydroelectric power generation plant, UHE Carlos Botelho (Itirapina Municipality, São Paulo State, Brazil), and its most extensive wetlands - total of 2,640 ha - and also identify the drivers of change of these services. Twenty (20) ecosystem services were identified and the estimated quantitative total value obtained was USD 120,445,657.87. year ${ }^{-1}$ or USD $45,623.35 \mathrm{ha}^{-1}$.year ${ }^{-1}$. Investments on restoration of spatial heterogeneity along Tietê-Jacaré hydrographic basin and new technologies for regional economic activities must maintain ecological functions as well as increase marginal values of ecosystem services and the potential annual economic return of ecological functions.
\end{abstract}

Keywords: neotropical reservoirs, ecosystem services, hydrographic basin management, cost-benefit analysis, wetlands, drivers.

\section{Serviços ecossistêmicos do reservatório da UHE Carlos Botelho (Lobo-Broa): uma nova abordagem para o gerenciamento e planejamento dos múltiplos usos de represas}

\section{Resumo}

Este estudo teve como objetivo identificar e valorar os serviços ecossistêmicos da UHE Carlos Botelho (Itirapina, Estado de São Paulo, Brasil) e suas áreas alagadas mais extensas e também identificar as forçantes de alterações nestes serviços. Vinte (20) serviços ecossistêmicos foram identificados e o valor quantitativo total estimado obtido resultou em USD 120.445.657,87. ano ${ }^{-1}$ ou USD 45.623,35 $\mathrm{ha}^{-1}$.ano ${ }^{-1}$. Investimentos na restauração da heterogeneidade espacial da bacia hidrográfica do Tietê-Jacaré e em novas tecnologias para as atividades econômicas regionais devem contribuir para a manutenção das funções ecológicas e para o aumento dos valores marginais e do valor potencial anual de retorno dos serviços ecossistêmicos.

Palavras-chave: reservatórios neotropicais, serviços ecossistêmicos, gerenciamento da bacia hidrográfica, análise custo-benefício, áreas alagadas, forçantes.

\section{Introduction}

Reservoir construction for hydroelectricity generation has been widely studied concerning its impacts on biota and human well-being through the adoption of Environmental Impact Assessment (EIA) protocols. To complement EIA protocols, Tundisi et al. (2008b) proposed a new approach for identifying positive and negative aspects of dam construction based on cost- benefit assessment through valuation of ecosystem services of reservoirs. Valuing ecosystem services, although difficult and uncertain, is an important tool to perceive how human welfare may be affected by their degradation (Costanza et al., 1997). For reservoirs, in which the construction processes modify most of the original terrestrial and aquatic ecosystem services, this analysis may be "an innovative way" to assess their local and regional significance, "providing a consolidated conceptual basis for future strategic plans on reservoir construction in the Neotropics" (Tundisi et al., 2008b).

It is essential to consider spatial and temporal scales of ecosystem services, and thus the assessment of its direct and indirect drivers (World Resources Institute, 2005) may be an essential tool to point out the main management actions needed to restore and maintain the ecosystem functioning along the hydrographic basin. This will guarantee the good functioning of the ecological processes of the reservoir and the services it provides for human well-being.

Theoretical studies of reservoir ecosystem services may contribute for a good epistemological development 
of an economic valuation theory of these aquatic systems for future cost-benefit analyses.

\subsection{UHE Carlos Botelho reservoir}

UHE Carlos Botelho reservoir is a good model for a theoretical study because it has been intensively studied by researchers from universities and other research institutions for at least 40 years in the areas of aquatic ecology, zoology, botany, geology and others, but there are few studies concerning the importance of ecosystem services for human well-being. This reservoir is located in the middle of São Paulo State $\left(22^{\circ} 15^{\prime} \mathrm{S}\right.$; $\left.47^{\circ} 49^{\prime} \mathrm{W}\right)$, Brazil (Figure 1), and pertains to Itirapina municipality. It is inserted in Tietê-Jacaré hydrographic basin and its main tributaries are the Lobo Stream and Itaqueri River, both with the most extensive wetlands.

Created in 1936, its main objective was to supply water for Carlos Botelho hydroelectric power generation plant (UHE), which provides energy in small scale (2000 kWh). Nowadays, the multiple uses of the reservoir contribute for local and regional development of environmental, social and economic activities. Land uses of this basin are characterised mainly by agriculture, reforestation, sand mining and cattle raising but there are also impacts of human waste derived from non-point sources and the non-efficient stabilization ponds of Itirapina $\mathrm{Mu}-$ nicipality (Tundisi et al., 2003).
The objective of this study is to identify the ecosystem services and their drivers of change in the UHE Carlos Botelho reservoir and the two main wetlands (Lobo and Itaqueri) with the purpose of constructing some background for management plans and contributing for future cost-benefit analyses of dam construction. In addition, this is a first attempt to organise an "ecological service data sheet" for a small but intensively used reservoir in São Paulo State, Brazil. This study may contribute for the construction of (a) an ecosystem service database of UHE Carlos Botelho reservoir and its marshes, (b) a background for future environmental management plans of Tietê-Jacaré hydrographic basin, and (c) a background for future cost-benefit analyses for the construction of new hydroelectric power plant reservoirs in the Neotropical region.

\section{Material and Methods}

For the assessment of ecosystem services with their ecological, social, and economic relations, a matrix was organised according to De Groot $(1992 ; 1994)$ where environmental services identified for the UHE Carlos Botelho reservoir and both wetlands were listed and matched with their corresponding benefits for human well-being: a) ecological values (conservation and existence value); b) social values (health); and c) economical values (consumption use value, productive use value and

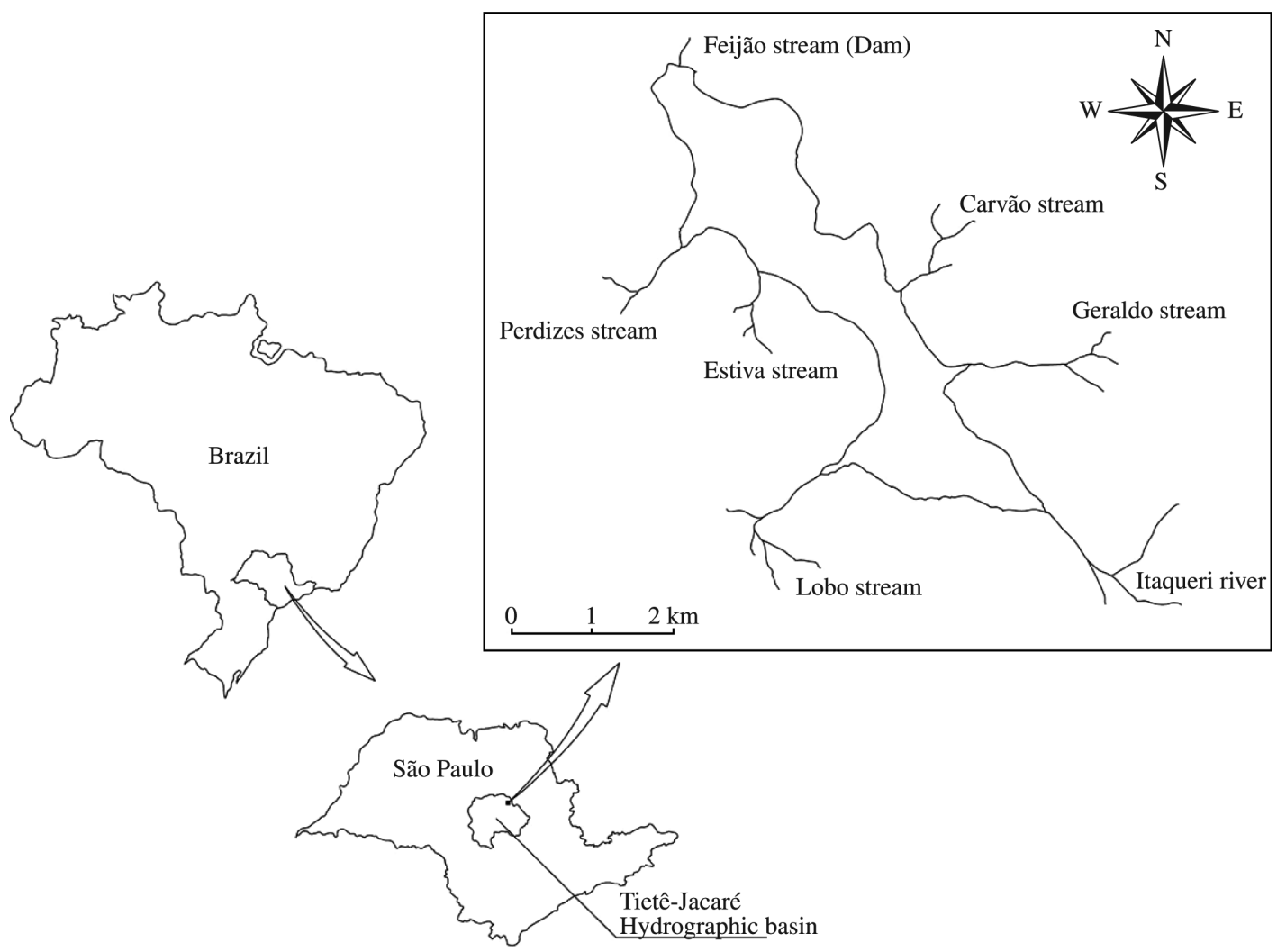

Figure 1 - Location of UHE Carlos Botelho reservoir, its tributaries and main wetlands, Itaqueri and Lobo. 
employment value). As this study does not use contingent methodologies, option values (correspondent to social values) were omitted as they reflect people's preferences for the future. Ecosystem services provided by the reservoir and wetlands were listed all together, due to their ecological interactions.

In this matrix, qualitative values were assigned for services that require contingent valuation as for example existence value, or other services that were not possible to input a value. Signals were used to express direct or indirect benefits: + (one positive signal), for services that indirectly affect human well-being; ++ (two positive signals), for services that directly affect human well-being. Quantitative values were estimated based on information acquired on scientific literature and oral communication. Calculations of quantitative values not only took into account the reservoir superficial area of $6.8 \mathrm{~km}^{2}$ (Tundisi et al., 2003), but Itaqueri River and Lobo Stream wetlands' total area of $19.6 \mathrm{~km}^{2}$ (Vergara, 1996) as these ecosystems interact. The total area considered in all calculations is $26.4 \mathrm{~km}^{2}$ or 2,640 ha. Currency conversion from Brazilian "Reais" to United States Dollars (USD) was obtained on the web site http: Ifinance.yahoo.com, with exchange rates from April $4^{\text {th }} 2011(\mathrm{R} \$ 1.00=$ USD 0.62; $1.00=$ USD 1.42). Carbon price was established as 14.00/ ton C (USD 9.90/ton C), according to estimates of
Brazil's Carbon Institute for the medium cost of carbon allowances on December 2010.

Direct and indirect drivers of change in ecosystem services were analysed according to the Millennium Ecosystem Assessment (2005) framework, where all the ecosystem services identified, and consequent main benefits for human well-being, direct and indirect drivers were listed in separate boxes and linked through arrows according to their influence on each other and considering that all these components operate on local, regional and global scales.

\section{Results}

Table 1 shows the ecosystem services identified for UHE Carlos Botelho reservoir and wetlands of Itaqueri River and Lobo Stream. The following paragraphs detail each service identified and valued. Figure 2 shows direct and indirect drivers of the services identified.

(a) Solar energy fixation (photosynthesis) and biomass production, (b) gas regulation and (c) oxygen production: Photosynthesis is a very important regulation function for all ecosystem services. Biomass production, which is a consequence of the photosynthesis process, may be used as an ecosystem good for human welfare and generate consumption, production and employment

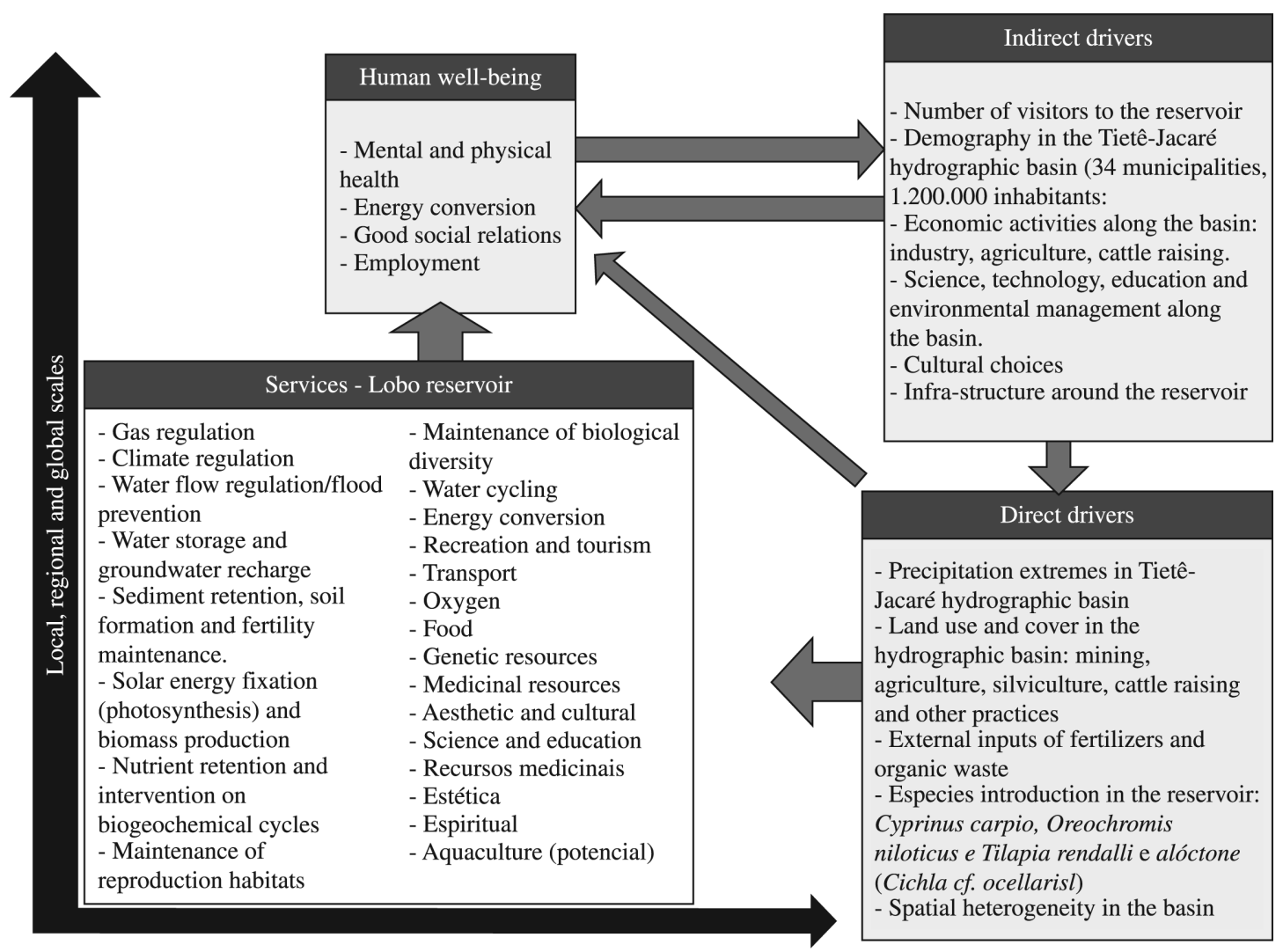

Figure 2 - Direct and indirect drivers of change in the Lobo Reservoir ecosystem services (Adapted from Millennium Ecosystem Assessment, 2005). 
Periotto, NA. and Tundisi, JG.

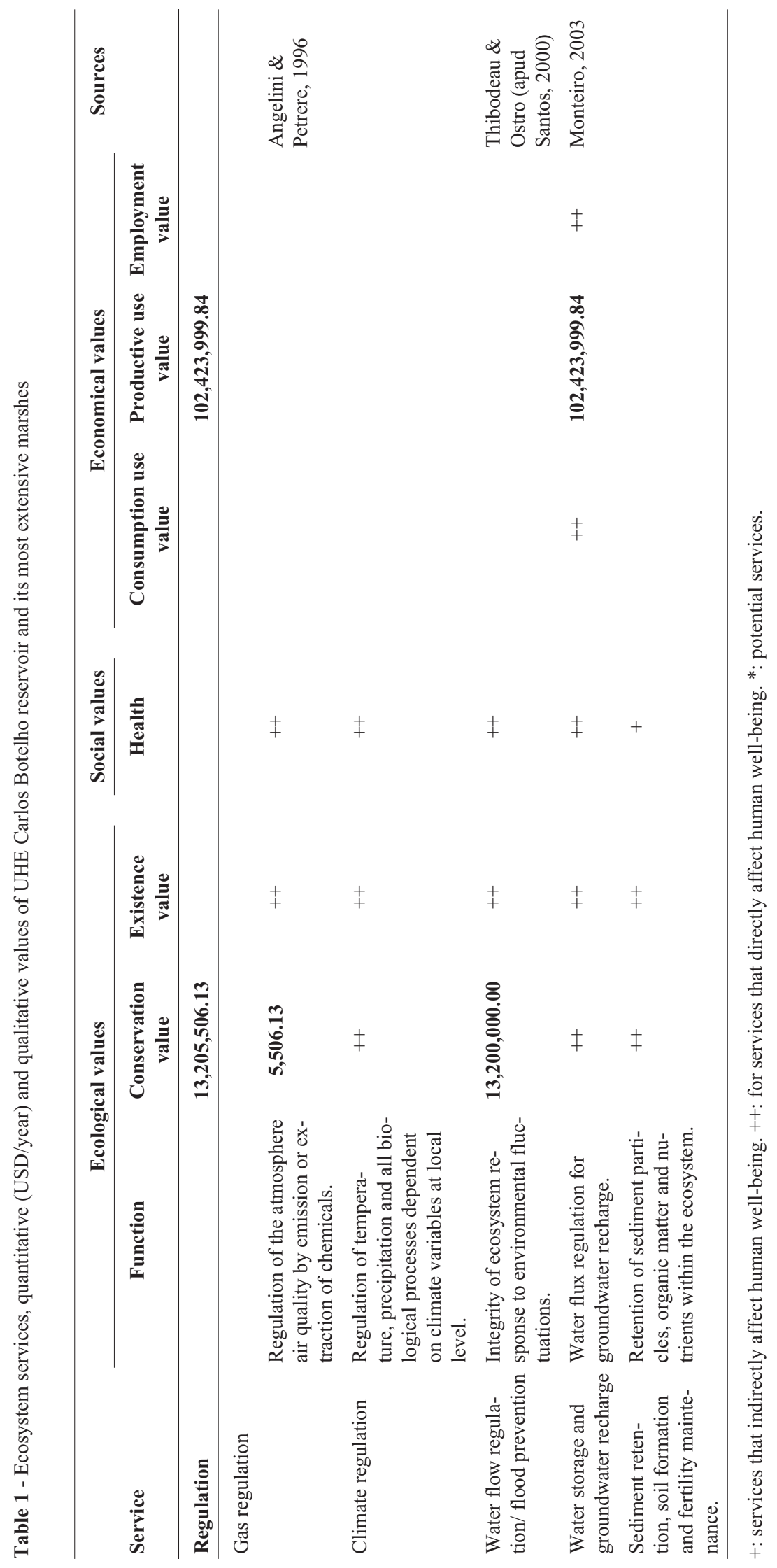


UHE Carlos Botelho reservoir ecosystem services

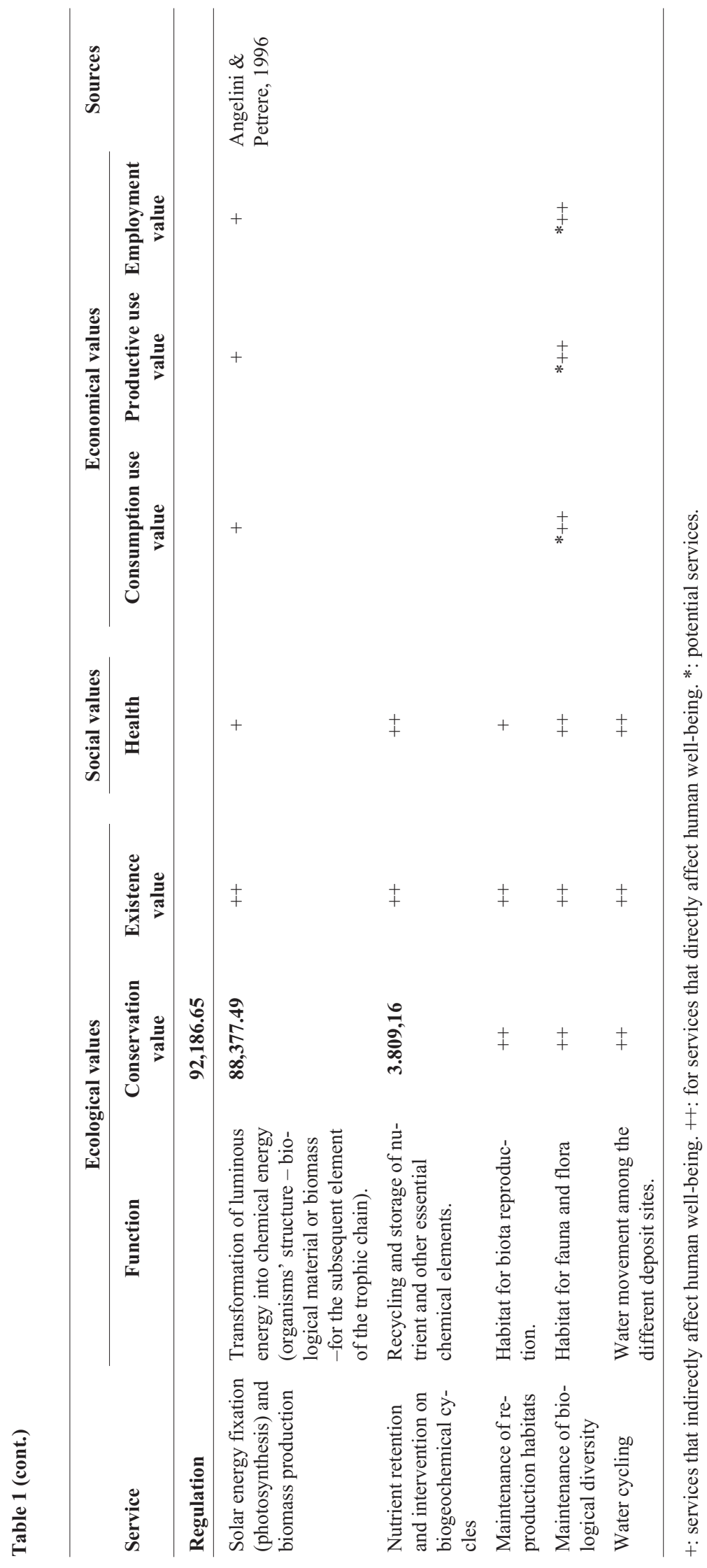


Periotto, NA. and Tundisi, JG.

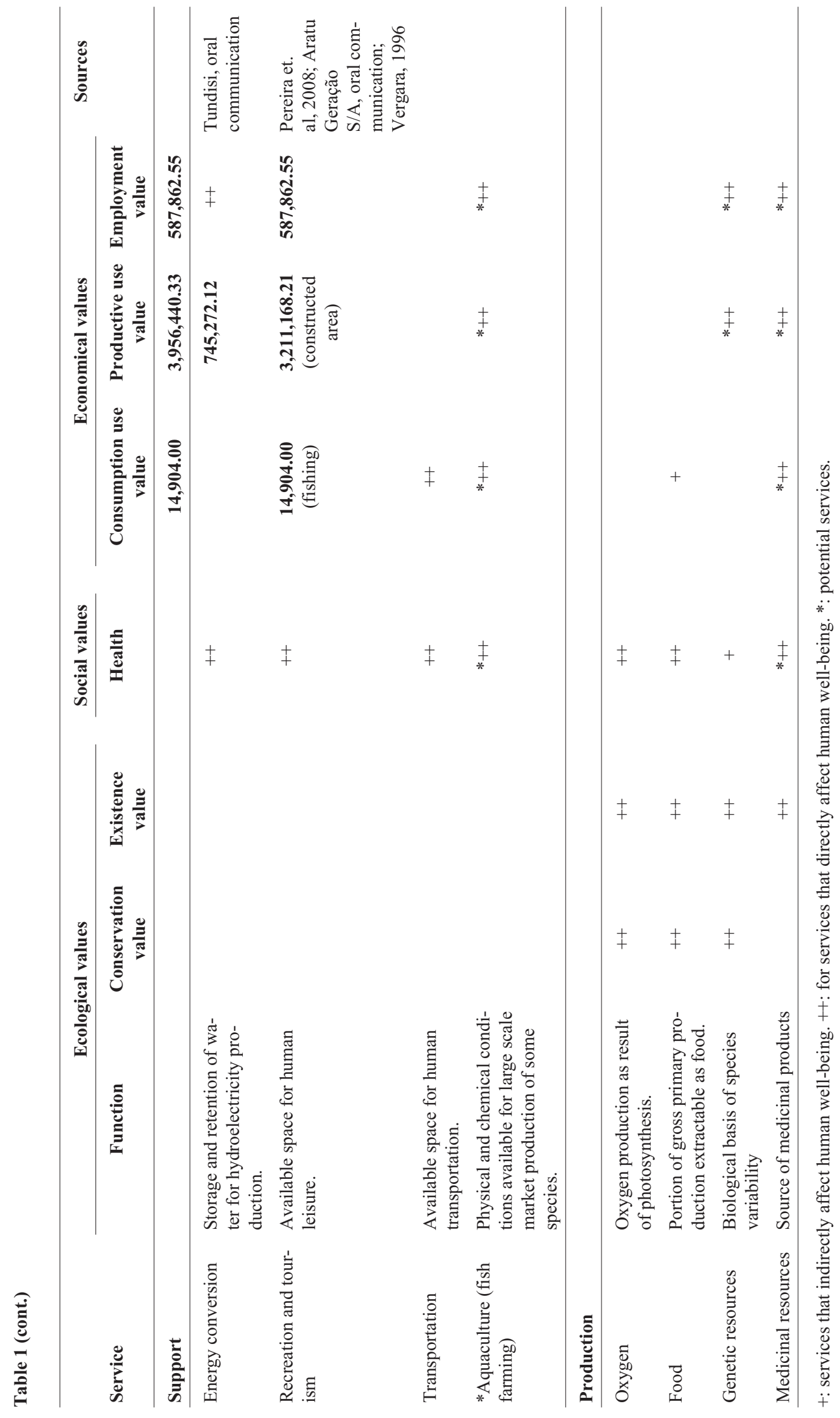




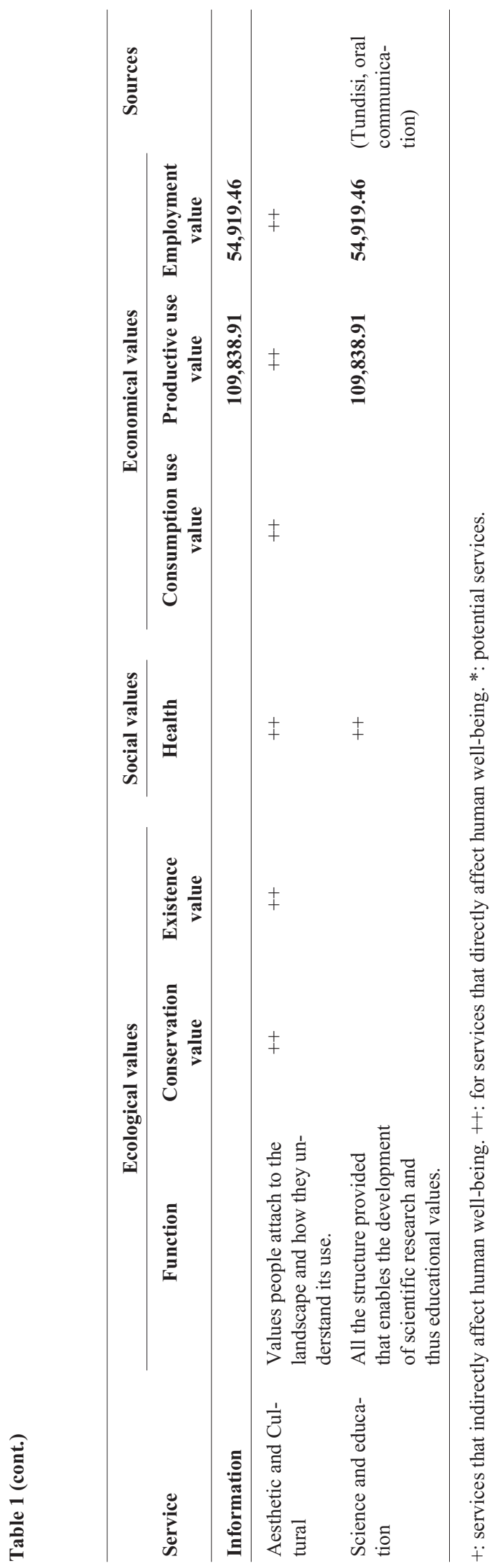

economic values. As social and economic benefits are indirect, they were scored with one qualitative signal. Primary production may express biomass production value. For this calculation, values of total primary production of the phytoplankton and some macrophytes were summed (Matheus and Tundisi apud Tundisi, 1988; Tundisi and Matsumura-Tundisi, 2008; Delello, 2008). Considering that macrophytes occupy $10 \%$ (68 ha) of the total superficial area of the reservoir the total estimated value for "solar energy fixation and biomass production" ecosystem service is USD 88,377.49 per year.

Consumption and release of carbon dioxide and oxygen resultant from photosynthesis and respiration regulate these gases in the atmosphere and in aquatic systems. Despite its meso-oligotrophic state, results obtained in Ecopath II modelling (Angelini and Petrere, 1996) show that the balance of total primary production/total respiration is positive. The estimated value for gas regulation ecosystem service is USD 5,506.13 per year. Two qualitative scores were attributed to existence and health values for its intrinsic importance and direct influence on human health.

As observed by Costanza et al. (1997) one single ecosystem function may result in more than one ecosystem service. Photosynthesis functions of extraction or release of gases may result in "gas regulation" and "oxygen production" ecosystem services. The latter is very important for reoxigenation of the aquatic systems. In order to avoid double valuation of this function, "oxygen production" was qualitatively valued with high ecological and social values.

Direct drivers: Release of organic (domestic and cattle raising wastes) and inorganic pollutants (fertilisers and pesticides residues) in Tietê-Jacaré hydrographic basin. Suspended organic matter may influence light penetration, affecting photosynthesis, absorption and production of gases and primary production. If organic matter accumulates in the reservoir it may require a high consumption of dissolved oxygen and cause anoxia, influencing the reservoir water quality.

Indirect drivers: Adequate environmental management, demography, economic activities and technologies influence these services. Scientific research on new technologies may soften direct drivers effects on ecosystem services. Environmental education related actions must bring knowledge to communities about the importance of indirect use of ecosystem services and of individual and collective contributions to the management of drivers for their own welfare. These actions may alter behaviour and the values people attach to the reservoir services, influencing on property values, for instance.

(d) Climate regulation, (e) water storage and groundwater recharge, (f) recreation and tourism, (g) water cycling, (h) energy conversion, (i) water flow regulation/flood prevention, (j) transportation: Reception of water flows from the basin water bodies and precipitation results in water storage which generates direct use services as energy conversion, recreation, flood preven- 
tion, and indirect use ones like local climate regulation, groundwater recharge and water cycling.

Energy conversion: According to the owner of UHE Carlos Botelho hydroelectric generation power plant (Aratu Geração S/A) the energy generated is sold for approximately USD 62,106.01 per month resulting in USD 745,272.12 per year passing directly through the market. This service positively impacts human well-being and employment, so that these values were highly qualitatively scored.

Recreation and tourism: This service generates expressive direct economic fluxes on local and regional economies by activities (aquatic sports, fishing and tourism in general) based on water storage. This quantitative value was inferred by summing up property values (houses constructed near the reservoir), fishing values (travel cost value) and employment value. Property value was estimated at USD 3,211,168.21 per year as productive use value, based on Vergara (1996). Fishing value (Pereira et al., 2008) was estimated at USD 14,904.00 per year, as consumption use value. Employment value was estimated considering costs of maintenance of 85 employees (Vergara, 1996) totalling USD $\mathbf{5 8 7 , 8 6 2 . 5 5}$ per year. The total estimated value for recreation and tourism ecosystem service is USD 3,977,878,76 per year. Social values were highly scored because recreation affects mental and physical human health.

Water storage and groundwater recharge: The area that embraces UHE Carlos Botelho reservoir and its wetlands is inserted in the Guarani Aquifer System (GAS) recharge area (Gomes et al., 2006). Based on Monteiro (2003) data of recharge rate and on market price of treated water provisioned by the Autonomous Service of Water and Wastewater of São Carlos Municipality (São Paulo State, Brazil), the resulting value is USD $102,423,999.84$ per year, which is considered as production use value since a great part of the water supply used in São Paulo State (Brazil) is groundwater. Water storage and groundwater recharge is of great importance for all ecological, social, and economic values, so high qualitative values were given to the ones that could not be quantified. Small scale extraction of groundwater (domestic wells) is very common in this region, as well as big scale extraction to supply municipalities, so groundwater recharge ecosystem service certainly has important influence on the regional economy and human wellbeing.

Water flow regulation/flood prevention: Disturbance prevention by the reservoir and wetlands, through the regulation of water flows during precipitation events is important to protect adjacent and downstream houses, home farms, recreation infra-structure and other properties from flooding and consequent damages to local economy and human health. According to Thibodeau and Ostro (apud Santos, 2000) the value of flood prevention of wetlands is USD5,000.00/ha/year. This value was inferred for the reservoir and wetland areas which resulted in USD13,200,000.00 per year as conservation value. High qualitative scores were given to existence and so- cial values as this service benefits biota, and avoid injuries to human health.

Water cycling and climate regulation: Reception and storage of water flows from the hydrographic basin and precipitation fluxes, evaporation, evapotranspiration, and groundwater infiltration are contributions of the studied area for water cycling. There is no direct measurement of the influence of the UHE Carlos Botelho reservoir and its wetlands on temperature and precipitation regulation in the region but it is known that evaporation of water from a water body does elevate local humidity and may ease local climate. This evaporative cooling creates a more comfortable environment for visitors' welfare and for biota that depend on humidity. These services - water cycling and climate regulation - were evaluated with a high score on conservation, existence and health values due to their high positive impacts on the maintenance of aquatic and terrestrial local ecosystems and on human well-being.

Transportation: The supply of water stored within the reservoir supports aquatic transport, which in this case, is used in recreation activities. This service was scored with the higher qualitative social and economic consumptive values as it influences human health, wellbeing, and the local economy.

Direct drivers: (1) Land cover and use along the hydrographic basin - which influence the discharge of fertilizers, pesticides and other chemical substances into water bodies, wetlands and UHE Carlos Botelho reservoir - have the potential to cause algae and other aquatic plants excessive growth, anoxia and eutrophication. This may impact the water quality of the reservoir for biota and recreation activities (fishing, swimming, etc.); transportation and energy conversion due to excessive growth of flora; the quality of water recharged to underground supply; and cause excessive sediment transportation from the basin to wetlands and reservoir, which reduces their depth and buffer capacity to soften the impacts of natural floods. (2) Precipitation extremes, which determine the quantity of water stored and directly influence hydroelectric generation, flood prevention and water quality. (3) The introduction of allochtonous fish species and consequent elimination of other fish species is known to be the cause of low frequency of fishermen in this reservoir (Pereira et al., 2008). (4) Spatial heterogeneity also influences water quality and quantity along the hydrographic basin, reservoir and wetlands. Indirect drivers: Demography and economy, which determine land cover and use along the basin and wastewater disposal; science and technologies that determine alternatives for economic activities; environmental management and education for the maintenance of spatial heterogeneity and water quality for human use.

(k) Nutrient retention and intervention on biogeochemical cycles: Wetlands provide water of good quality - maintenance of low conductivity and organic matter concentration - for recreation for UHE Carlos Botelho reservoir (Tundisi and Matsumura-Tundisi, 2003). Whi- 
taker et al. (1995) studied three different compartments (sediment, interstitial water and water layer above water-sediment interface) of Lobo Stream and Itaqueri River wetlands and verified that 13 to $20 \%$ of nitrogen coming from upstream water bodies is recycled in these wetlands. Tundisi et al. (2003) estimated a cost of USD $1,428,438.34$ for the implementation of a wastewater treatment plant in this area. This value may be considered as a replacement cost as the wastewater treatment plant represents a substitution of ecosystem services. Considering the maximum nitrogen treatment percentage $(20 \%)$ (Whitaker et al., 1995) of the wetlands, and the extrapolation of this percentage for other chemical elements (Tundisi et al.,2003), a value of USD 285,687.66 is obtained. Dividing this value for the reservoirs "age", 75 years, "nutrient retention and intervention on biogeochemical cycles" ecosystem service is estimated at USD 3,809.16 per year. High qualitative values were given for existence and social values, as biogeochemical cycling directly affects ecosystem functioning and human health. It must be observed that the study of this ecosystem service highlights (a) the role of some biogeochemical processes of wetlands, and (b) the need to repair the existent stabilization ponds in Itirapina Municipality in order to treat human wastewater before disposing it back to the river basin, as required by adequate sanitation and environmental management policies.

Direct drivers: Precipitation extremes, land cover and use, and spatial heterogeneity along the hydrographic basin. Agricultural activities, cattle raising and sand mining on Tietê-Jacaré basin, result in non-punctual discharge of organic waste, metal, fertilisers and pesticides residues into water bodies. Wetlands treat efficiently the organic and inorganic loads, but if precipitation events in the basin are scarce, there will be lower dilution of pollutants in water, an excess in the treatment capacity of wetlands and in consequence changes in reservoir water quality for human recreation. Spatial heterogeneity (vegetation mosaics) along the hydrographic basin regulates biogeochemical cycles, influencing water quality parameters (Tundisi and Matsumura-Tundisi, 2010) of the UHE Carlos Botelho reservoir water supply. Indirect drivers: Demography and economy along the hydrographic basin. New technologies developed by scientific research may bring alternatives to agriculture, cattle raising and mining, and decrease punctual and non-punctual discharge of pollutants into water bodies.

(l) Sediment retention, soil formation and fertility maintenance: Reservoirs retain suspended matter that comes from its tributaries (Tundisi and MatsumuraTundisi, 1990; Tundisi et al., 2008a). Despite some negative impacts, the retention of suspended matter in UHE Carlos Botelho reservoir may reduce downstream turbidity, benefitting primary production. In wetlands, retention of organic matter and trap of nutrients in sediment particles result in soil formation, which maintains local productivity, biodiversity and good water quality in the reservoir for human well-being. Ecological values were scored with two high qualitative values, as this service is important for the maintenance of local ecological productivity. One qualitative value was given to social health value, as it indirectly affects human health.

Direct drivers: Land cover and use and spatial heterogeneity on Tietê-Jacaré hydrographic basin are the main direct drivers of this service. Vegetation mosaics regulate erosion and suspended solid transport (Tundisi and Matsumura-Tundisi, 2010). On the other hand, economic activities that remove vegetation cover such as agriculture, cattle raising and sand mining, increase soil erosive potential and suspended solid transport. Indirect drivers: economy and demography along the hydrographic basin; environmental management, education and policies, which may influence on how land is explored and altered.

(m) Maintenance of biological diversity, (n) maintenance of reproduction habitats, (o) genetic resources, (p) medicinal resources, (q) food, (r) aquaculture:

Maintenance of biological diversity: Wetlands and reservoirs play an important role in maintaining habitats for fauna and flora species not only from their aquatic systems, but also for resident and transient terrestrial species. Several studies in this reservoir have registered the presence of many flora and fauna aquatic species, ranging from phytoplankton, zooplankton and other invertebrates to macrophytes and fishes (Peláez-Rodriguez and Matsumura-Tundisi, 2002; Pereira et. al, 2008; Dellelo, 2008; Luzia, 2009). There are also records of terrestrial fauna (Motta-Júnior, 2008; Sawaya et al., 2008) that certainly use the reservoir and wetlands for water, habitat, food and breeding. It is a complex task to give economic value to biodiversity. But it is certain that interactions between species and the physical and chemical environment result in biological resources (goods) or ecosystem services for human welfare. The value of biodiversity can be mapped using species' richness (Williams et al., 1997), but quantifying it in terms of monetary value must require a more elaborate analysis maybe through a biophysical approach (Jörgensen, 1992; Green et.al, 1994). High qualitative ecological and social values were given for the "maintenance of biological diversity" service. It is believed that although not quantified, biodiversity represents a significant ecological value because it is "a necessary precondition for the long term maintenance of biological resources" (Wood, 1997), that is, the other ecosystem services derive from it. In addition, high scores were attributed because the research area is protected by law as a "wild life zone" (São Paulo State Decree No. 20.960, June $8^{\text {th }}$ of 1983). Biological diversity maintenance also presents potential direct use, productive use and employment economic values (Agostinho et al., 2009; Alho and Sabino, 2011).

Maintenance of reproduction habitats: The landscape features of UHE Carlos Botelho reservoir and its wetlands, their chemical conditions, amongst other characteristics, offer nursery ground for the reproduction of species of fauna and flora, which contributes for biologi- 
cal diversity maintenance. "Maintenance of reproduction habitats" ecosystem service was valued with a high score (two positive signals) for ecological values, and with one signal for social value as it indirectly affects human health.

Genetic resources and medicinal resources: "Genetic resources" and "medicinal resources" ecosystem services are consequences of local biodiversity. For ecological values of genetic resources service, two qualitative signals were assigned because genetic variability in populations is important for species survival. One qualitative signal was attributed for social value as this service indirectly affects human health. Two qualitative signals were assigned to the existence value of "medicinal resources" service, for its future value to human populations. Both genetic and medicinal resources present potential social and economic values, if investments in science are made on molecular genetics and medicinal chemistry research focused on human well-being.

Food availability is also a consequence of habitat refuge and biodiversity. This service, in UHE Carlos Botelho reservoir is represented by small scale fishing (direct consumption) with rare cases of commercial exploring as verified by Pereira et. al (2008) but with direct consumption value. The ecosystem service "food" production was valued with two qualitative signals for ecological and social values.

Aquaculture: Fish farming or aquaculture is an ecosystem service with potential to be developed in the UHE Carlos Botelho reservoir. Angelini and Petrere (1996) and Angelini (2002) showed through Ecopath modelling software that the reservoir is able to support Piaractus mesopotamicus farming if efficiently managed concerning reservoir water quality. Potential direct use values can be developed, including human health, consumption, productive use and employment ones.

Direct drivers: Direct drivers for the services reported are the following: (1) Land cover and use along Tietê-Jacaré hydrographic basin. Pollutants (pesticides and fertilizers) discharge into water bodies and sand mining that increase erosion potential, may change reservoir and wetlands water quality (concerning chemical substances) and physical refuge (related to sediment transportation) for biota. (2) Allochtonous fish species introduction, which have already been confirmed to have diminished reservoir fish species and recreational fishing activities. According to Fragoso et al. (2005) the reservoir contains 4 allochtonous fish species: Cyprinus carpio, Oreochromis niloticus, Tilapia rendalli and Cichla cf. ocellaris. It is believed that Cichla cf. ocellaris have eliminated some other fish species by predation; this information is confirmed by fishers report on the loss of fish species (Pereira et. al, 2008). (3) Spatial heterogeneity in the hydrographic basin, along upstream water bodies (to the reservoir), influence water quality, sediment and nutrient loads and energy fluxes that flow to wetlands and reservoirs, causing alteration in microhabitats. Riparian forests, vegetation mosaics and wetlands are buffer systems of the hydrographic basin
(Tundisi and Matsumura-Tundisi,2010), and also influence groundwater recharge and the diversity of biota species. The more heterogeneous the system is, the higher the probability of having several ecosystem services being offered (Wilson and Peter, 1998).

Indirect drivers: demography, economy, technology, science, environmental management and education.

(s) Aesthetic and cultural services: Local environmental quality is of great importance for aesthetic values of the UHE Carlos Botelho reservoir, because it enhances recreational values. Aesthetic is an important service since it motivates the presence of visitors and their wellbeing. It also influences visitor's cultural choices, that is, how people understand and consume local natural resources. It certainly generates local consumptive values, production and employment values. Two qualitative signals were assigned to ecological, social and economical values, as a pleasing landscape may mean an ecosystem with good functioning of its ecological interactions.

Drivers: All direct and indirect drivers considered in other ecosystem services influence reservoir and wetlands environmental quality, altering aesthetic and cultural values.

(t) Science and education: Research on UHE Carlos Botelho reservoir and its surrounding areas (including its wetlands) started in 1971 by the Federal University of São Carlos - UFSCar (Brazil). In 1976, the Center for Water Resources and Applied Ecology - CRHEA - of São Paulo State University (Brazil) made high investments in the CRHEA building construction and then in research on climatology, transport phenomena, hydraulics, environmental politics, hydrometry, among others. A post-graduation program at UFSCar was created in the same year focusing on studies in this reservoir and its wetlands on zoology, botany and ecology among other research areas, with the support of scholarships and fomentation agencies. Approximately R $\$ 2,000,000.00$ was invested in the CRHEA construction and RS $5,500,000.00$ on initial researches (oral communication with Prof. Dr. José Galizia Tundisi).

This information service - science and education was calculated by adding CRHEA initial investments to estimated investments on post-graduation scholarships at UFSCar. Summing up the CRHEA initial investments and dividing the result by its existence time (35 years) it is obtained at approximately $\mathrm{R} \$ 214,285.71$ (USD $133,084.31)$ per year. Assuming that the UFSCar postgraduation ecology programme has 20 Masters Degree students per year with scholarships of R $\$ 1,200,00$ and 15 Doctorate students per year with scholarships of $\mathrm{R} \$ 1,800.00$, the estimated value obtained is USD $31,674.06$ per year. The sum total of CRHEA and UFSCar values results in USD 164,758.37 per year. Considering that $1 / 3$ of this value is destined to support employment (value of scientific publications), the value for science and education ecosystem service is estimated at USD 109,838.91 per year (productive use value) in ad- 
dition to USD 54,919.46 per year (employment value). High qualitative social value was considered as research results tend to improve the hydrographic basin quality, including UHE Carlos Botelho reservoir and wetlands, benefiting human well-being.

Although the value of this ecosystem service is underestimated due to a lack of precise quantitative information, it is generated by high economical investments. These high investments in research for the UHE Carlos Botelho reservoir have produced significant scientific background knowledge and turned this aquatic system into one of the most studied lentic tropical systems.

\section{Conclusions}

A total of 20 ecosystem services were identified for the UHE Carlos Botelho (Lobo-Broa) reservoir and its main wetlands (pertaining to Itaqueri River and Lobo Stream).

Qualitative values emphasize the importance of indirect (regulation functions mainly) uses of ecosystem services, which are the basis for the other ones.

Quantitative values were estimated at USD 120,445,657.87 year $^{-1}$ or USD 45,623.35 $\mathrm{ha}^{-1}$.year ${ }^{-1}$. Although being a preliminary analysis, with no field data collection, this result shows the importance of direct (as recreation and scientific research) and indirect use (as groundwater recharge and flood prevention) services for the local and regional economy and indicate the economic magnitude of their loss, if they are not properly managed. Final quantitative values also indicate the potential annual economic return of ecological functions, and may be altered to a higher or lower value according to direct and indirect drivers management.

Recreation and tourism is the direct use service with higher estimated quantitative value. As this service contributes to the local and regional economy it is important to efficiently manage its drivers of change along the hydrographic basin. In addition, as this service depends on environmental quality, managing it adequately would also ensure the maintenance of the ecological processes of the reservoir and upstream and downstream areas.

The analysis of interactions between drivers, ecosystem services and human well-being indicates that maintenance and improvement of ecosystem services depend mainly on: (1) adequate management of regional economic activities, highlighting the need to develop new technologies that avoid the disposal of pollutants and sediments into Tietê-Jacaré hydrographic basin, and (2) the recovery of spatial heterogeneity along the basin, especially riparian forests, through incentives of public policies for land owners. In future management plans of Tietê-Jacaré hydrographic basin, it should also be taken into account that spatial and temporal scales of ecosystem services and interactions between services of adjacent hydrographic basins as well as ecological functions, processes and interactions are not limited to specific boundaries.
More detailed studies and field applications of evaluation methodologies must be carried out in the UHE Carlos Botelho reservoir and wetlands, (1) to obtain a complete value of the studied area and (2) to consolidate a good epistemological development of the economic valuation theory of reservoirs ecosystem services in order to complement cost-benefit analyses for the construction of new reservoirs for hydroelectricity generation in the Neotropical region.

\section{Acknowledgments}

To CNPq (process number 556687/2009-4). To Gustavo Rincon Mazão for the map.

\section{References}

AGOSTINHO, AA., BONECKER, CC., RODRIGUES, L., GOMES, LC. and THOMAZ, SM., 2009. Biodiversity and conservation. Brazilian Journal of Biology, vol. 69, no. 2, supplement, p. 459-755.

ALHO, CJR. and SABINO, J., 2011. A conservation agenda for the Pantanal's biodiversity. Brazilian Journal of Biology, vol. 71 , no. 1 , supplement, p. 229-341.

ANGELINI, R., 2002. Avaliação da capacidade-suporte da represa do Broa para a colocação de tanques-rede. Revista Saúde e Ambiente / Health and Environment Journal, vol. 3, no. 2, p. 42-48.

ANGELINI, R. and PETRERE JUNIOR, M., 1996. The ecosystem of Broa reservoir, São Paulo, State, Brazil, as described using ECOPATH. NAGA, vol. 19, no. 2, p. 36-41.

COSTANZA, R., D'ARGE, R., DE GROOT, R., FARBER, S., GRASSO, M., HANNON, B., LIMBURG, K., NAEEM, S., O'NEILL, RV., PARUELO, J., RASKIN, RG., SUTTON, P. and VAN DEN BELT, M., 1997. The value of the world's ecosystem services and natural capital. $\mathrm{Na}$ ture, vol. 387, p. 253-260.

DE GROOT, RS., 1992. Functions of Nature: Evaluation of Nature in environmental planning management and decision making. Amsterdam: Wolters-Noordhoff. 315 p.

-, 1994. Environmental functions and the economic value of natural ecosystems. In JANSSON, A., HAMMER, M., FOL$\mathrm{KE}, \mathrm{C}$. and COSTANZA, R. Investing in natural capital: the ecological economics approach to sustainability. New York: Island Press. $511 \mathrm{p}$.

DELELLO, D., 2008. Composição e distribuição (espacial e temporal) de macrófitas aquáticas no Reservatório do Lobo (Broa), Itirapina/Brotas, SP. 2008. São Carlos: Escola de Engenharia de São Carlos, Universidade de São Paulo. 160 p. Dissertação de Mestrado em Ciências da Engenharia Ambiental.

FRAGOSO, EN., SOUZA, JE., VELUDO, MR., SOARES, AS., SILVA, LH., RODRIGUES-FILHO, JL., FENERICH-VERANI, N., VERANI, JR. and ROCHA, O., 2005. Introdução de espécies e estado atual da ictiofauna da represa do Lobo, Brotas-Itirapina, São Paulo. In ROCHA, O., ESPÍNDOLA, ELG., FENERICH-VERANI, N., VERANI, JR. and RIETZLER, AC. (Orgs.). Espécies invasoras em águas doces: estudos de caso e propostas de manejo. São Carlos: EdUFSCar. p. 47-58.

GOMES, MAF., FILIZOLA, HF. and SPADOTTO, CA., 2006. Classificação das áreas de recarga do Sistema Aquífero Guarani no Brasil em domínios pedomorfoagroclimáticos - subsídio aos estudos de avaliação de risco de conta- 
minação das águas subterrâneas. Revista do Departamento de Geografia, vol. 1, p. 67-74.

GREEN, IM., FOLKE, C., TURNER, K. and BATEMEN, I., 1994. Primary and secondary values of wetland ecosystems. Environmental and Resources Economics, vol. 4, p. 55-74.

JÖRGENSEN, SE. 1992. Integration of ecosystem theories: a pattern. Dordrecth: Kluwer Academic Publishers.

LUZIA, AP., 2009. Estrutura organizacional do fitoplâncton nos sistemas lóticos e lênticos da bacia do Tietê-Jacaré (UGRHI Tietê-Jacaré) em relação à qualidade da água e estado trófico. 28 de agosto de 2009. São Carlos: Universidade Federal de São Carlos. 169 p. Tese de Doutorado em Ecologia e Recursos Naturais.

MILLENNIUM ECOSYSTEM ASSESSMENT, 2005. Ecosystems and human well-being: wetlands and water: synthesis. Washington: World Resources Institute.

MONTEIRO, RC., 2003. Estimativa espaço-temporal da superficie potenciométrica do Sistema Aquífero Guarani na cidade de Ribeirão Preto (SP), Brasil. Rio Claro: Instituto de Geociências e Ciências Exatas, Universidade Estadual Paulista. 212 p. Tese de Doutorado em Geociências.

MOTTA-JÚNIOR, JC., GRANZINOLLI, MAM. and DEVELEY, PF., 2008. Aves da Estação Ecológica de Itirapina, Estado de São Paulo, Brasil. Biota Neotropica, vol. 8, no. 3, p. 207-227.

PELÁEZ-RODRÍGUEZ, M. and MATSUMURA-TUNDISI, T., 2002. Rotifer production in a shallow artificial lake (Lobo-Broa reservoir, SP, Brazil). Brazilian Journal of Biology, v. 62, no. 3, p. 509-516.

PEREIRA, JMA., PETRERE-JUNIOR, M. and RIBEIROFILHO, RA., 2008. Angling sportive fishing in LoboBroa reservoir (Itirapina, SP, Brazil). Brazilian Journal of Biology, vol. 68, no. 4, p. 721-731.

SANTOS, JE., NOGUEIRA, F., PIRES, JSR., OBARA, AT. and PIRES, AMZCR., 2000. Os valores dos services dos ecossistemas e do capital natural da Estação Ecológica de Jataí (Luiz Antônio, SP). In SANTOS, JE. and PIRES, JSR. Estudos integrados em ecossistemas: Estação Ecológica de Jataí. São Carlos: Rima. vol. 1, p. 95-119.

SAWAYA, RJ., MARQUES, OAV. and MARTINS, M., 2008. Composição e história natural das serpentes de Cerrado de Itirapina, São Paulo, sudeste do Brasil. Biota Neotropica, vol. 8 , no. 2 .

TUNDISI, JG., 1988. Limnologia e manejo de represas. São Paulo: USP, ACIESP, FAPESP, UNEP. v. 1, tomos 1 e 2, p. 419-472. (Série Monografias em Limnologia).
TUNDISI, JG. and MATSUMURA-TUNDISI, T., 1990. Limnology and eutrophication of Barra Bonita reservoir, S. Paulo State, Southern Brazil. Ergebnisse der Limnologie, vol. 33, no. 3, p. 661-676.

-, 2003. Integration of research and management in optimizing multiple uses of reservoirs: the experience in South America and Brazilian case studies. Hydrobiologia, vol. 500, p. 231-242.

-, 2008. Limnologia. São Paulo: Oficina de Textos. 637 p.

-, 2010. Impactos potenciais das alterações do Código Florestal nos recursos hídricos. Biota Neotropica, vol. 10, no. 4, p. 67-76.

TUNDISI, JG., MATSUMURA-TUNDISI, T. and ABE, DS., 2008a. The Ecological dynamics of Barra Bonita (Tietê, River, SP, Brazil) reservoir implications for its biodiversity. Brazilian Journal of Biology, vol. 68, no. 4, supplement, p. 913-1135.

TUNDISI, JG., MATSUMURA-TUNDISI, T. and RODRIGUES, S., 2003. Gerenciamento e recuperação das bacias hidrográficas dos Rios Itaqueri e do Lobo e da Represa da UHE Carlos Botelho (Lobo-Broa). São Carlos: IIE, IIEGA. $72 \mathrm{p}$.

TUNDISI, JG., MATSUMURA-TUNDISI, T. and TUNDISI, JEM., 2008b. Reservoirs and human well being: new challenges for evaluating impacts and benefits in the Neotropics. Brazilian Journal of Biology, vol. 68, p. 11331135.

VERGARA, FEF., 1996. Avaliação econômica de ambientes naturais: O caso das áreas alagadas. Uma proposta para a Represa do Lobo (Broa), Itirapina-SP. São Carlos: Escola de Engenharia de São Carlos, Universidade de São Paulo. 143p. Dissertação de Mestrado em Ciências da Engenharia Ambiental.

WHITAKER, VA., MATVIENKO, B. and TUNDISI, JG., 1995. Spatial heterogeneity of physical and chemical conditions in a tropical reservoir wetland. Lakes \& Reservoirs, vol. 1, p. 169-176.

WILLIAMS, PH., GASTON, KJ. and HUMPHIRES, CJ., 1997. Mapping biodiversity value worldwide: combining higher-taxon richness from different groups. Proceedings of the Royal Society London B, vol. 264, p. 141-148.

WILSON, EO., PETER, FM., 1998. Biodiversity. Washington: National Academy Press. 521 p.

WOOD, PM., 1997. Biodiversity as the source of biological resources: a new look at biodiversity values. Environmental Values, vol. 6, no. 3, p. 251-268.

WORLD RESOURCES INSTITUTE, 2008. Ecosystem services: a guide for decision makers. Washington DC: World. Resources Institute. 80 p. 